\title{
THE ROLE OF TRUST IN SHORT FOOD SUPPLY CHAINS
}

\author{
Antónia Szűcs - Gábor Koncz
}

\begin{abstract}
The purpose of this study is to examine the role of trust in Short Food Supply Chains (SFSC) through national and international literary analysis. As local products are usually available at higher prices due to the small volume of production, local producers need to convince consumers in other ways. In addition, it is extremely important to retain the acquired consumer base, as small producers often intervene for survival. First, we write about trust as a general idea, then the concept of SFSC will be briefly defined, to create points of contact between the two topics. Next, we discuss the extent of trust through the presentation of various research findings. In general, the level of trust in Hungary lags behind the European average, which requires active communication on the part of small producers. At the same time, consumers' trust also means positive feedback for producers, strengthening them. Finally, our study summarizes the areas of trust in SFSCs, and in our conclusions we deal with its effects of rural development.
\end{abstract}

Keywords: trust, local product, local economic development, Short Food Supply Chains JEL: R10 


\section{Introduction}

\section{The objectives of the study}

In our previous research, we examined the rural development and sustainability issues of short food supply chains from several aspects (Koncz-Szücs, 2018). These studies highlighted the importance of trust in developing and maintaining alternative forms of sales. Therefore, we considered it important to perform a literature review focusing directly on the role of trust in SFSCs. After defining our main concepts, we present literature information on measuring the degree of trust and describing its role in SFSCs.

\section{Definition of trust}

There are many definitions in the national and international literature for defining the concept of trust. There was so much interest in this topic that the number of related publications doubled between 1994 and 1999 (Tarnai, 2003). Bencsik-Juhász (2016) focus on willingness, and in their view, trust is the readiness to have a positive attitude towards the actions of others. Sass et al. (2008) emphasize reliability, trust is interpreted as a psychological state, reflects the trust giver's judgment of trust regarding the trust taker's behaviour and intentions. So, emotion is an important basis for trust, positive emotions increase credit, while negative ones reduces it. However, trust is partly a rational phenomenon, that is, based on past experience or reliable information, we have good reason to rely or not to rely someone (Hardin, 2002). Kumar (1996) it also emphasizes reliability, the members of the supply chain trust each other and unconditionally respect their words. A corporate supply chain approach is a business philosophy that requires assurance, commitment, alignment, common goals, senior management support, and understanding and acceptance of interdependence (Németh, 2009).

\section{Short Food Supply Chains}

Consumers, as long as food production and consumption were close in space, could be assured of quality. However, consumer confidence has been increasingly shaken by growing food scandals (Beulens et al., 2005). As a result, the need for healthy and reliable food has increased. According to Regulation (EU) No 1305/2013 of the European Parliament Council, the Short Supply Chain is a supply chain made up of a small number of operators committed to cooperation, local economic development and the close geographical and social relationships between producers, processors and consumers. There are several aspects in the literature of grouping short food chains such as: physical distance of sales, territorial attachment of sales, marketing channels, number of participants and form of participation, physical form of sales (Kujáni, 2014). In addition, it is important to distinguish between SSC and SFSC. SSCs are local, regional supply chains that include non-food handicraft products made by producers, while SFSCs are only the food chain. Our study focuses on the latter one. 


\section{Material and methods}

The research topic areas were summarized, such as the Short Supply Chain and trust and their relationships, based on national and international literature. In addition, we also attempted to briefly summarize previous research results on the topic through secondary information collection.

\section{Results and discussion}

\section{Trust and its measure}

In general, trust definitions can be categorized into two basic approaches. One is a belief based approach and the other is a risk concept. According to belief-based approaches, the source of trust is the belief in each other. Both parties have an interest in maintaining the prosperity of the other (Nagy-Schubert, 2007), however, cooperation always involves some risk. According to Das-Teng (2004), trust means that we voluntarily take the risk of being vulnerable by the other party.

The difference between cooperation and trust lies in the fact that risk-taking is not necessarily required for two parties to cooperate. From this point of view, trust is relevant in relationships which are characterized by risk. A high level of cooperation is essential to maintain the competitiveness and performance of companies (Benedek-Takácsné, 2016), while long-term business relationships have a positive impact on trust.

Positive cooperation and credence between people is part of the social capital. This capital plays an important role in social reproduction, including the future development of well-being. However, reliance and cooperation can only be truly outstanding in countries where social capital is strong. Economic operators are turning to each other consciously in order to establish economic recovery relationships (Varga, 2013).

According to the survey of Hungarian Central Statistical Office, the level of trust between people in Hungary is moderate on a scale of 10 . The value of the indicator decreased between 2013 and 2015, from 5.30 to 4.95. Hungary's trust index is lower than the European Union value (5.8). Mutual trust is strongest in the Scandinavian countries, with Denmark showing a particularly high value. The level of trust is the lowest in Bulgaria, where the average index was 4.2 points. Among our neighbours, the level of trust was lower in Croatia than in Hungary, while in the Czech Republic the average is equal to the Hungarian population (KSH, 2018).

Examining the Hungarian agricultural operators, the cooperation activity of Hungarian farmers is far below that of the developed Western European countries. Research on this topic has identified low levels of trust as one of several reasons for low willingness to cooperate (Takács-Baranyai, 2010). In their study BaranyaiSzabó (2016) examine the factors affecting reliance in Hungarian agriculture. 
Their research has shown that the loyalty dimension plays a more important role in building reliance than belief in professional competence. Therefore, continuous bilateral communication between supply chain members is essential to reduce the level of uncertainty (Piricz, 2013).

\section{The role of trust in SFSCs}

These forms of cooperation are typically based on social consensus, relying on personal or community trust in producer-consumer cooperation. Their aim is to exchange quality products, guaranteeing the origin of the product, which is typically a priority for the customer (Balázs, 2011).

Trust is therefore a key aspect of the sustainability assessment of SFSCs. The basis of the cooperation between SFSC actors is trust and commitment, and its continuous improvement. It is important for members to accept interdependence and to share the information available to them (Ványi-Varjasi, 2014). In a survey conducted in the Balaton region, the importance of various influencing factors in the sales of local products was assessed on a scale of 1-10. The ranking of factors was clearly driven by trust (average: 9,24). In their opinion, trust is both expectation and compulsion in a good sense which keeps farmers in a good position and a guarantee of quality (Balatoni Integrációs Közhasznú Nonprofit Kft., 2017).

According to Gelei (2002), the primary goal of supply chain members is to meet consumer needs by working together in value-creating processes while sharing both risk and reward.

From a consumer perspective, it has real value to buy food from a producer we know personally. As a result of Byker and co-authors' (2012) consumer attitudes survey, they say that the main reason for the popularity of local products is the quality of the products which has been purchased. According to HendricksonHeffernan (2002) consumer trust is not about good product quality, but about safe product production, and this is a guarantee of personal contact.

Benedek-Balázs (2014) discuss the relationship between trust and certification. According to Jarosz (2008) most producers do not have any certification due to more important trust between producers and consumers. The existence of certificates proves for many people just that the product (or method of production) has not been integrated into the local environment (Watts et al., 2005).

\section{Conclusions}

The need for trust lies in the fact that cooperation between partners is the only way to meet consumer needs at the highest level and at the lowest cost. What really 
distinguishes trust-based business relationships from the rest is the commitment the partners feel to each other.

A local product of a region is a confidential product. Consumer trust or distrust affects the path, success, or failure of a product. In many cases, the production of a reliable, quality local product is based on tradition, and the knowledge and experience of the producers play an important role. It is a real value for the consumers, if the right climate of reliance is created. So they knows exactly where and what the producer has grown for them. In this way, the general effect of SFSC is to improve general reliance and strengthen social cohesion.

The local market is primarily a complex economic development tool. Providing an appropriate relationship of trust among producers and between producers and consumers may trigger the rural development effects of SFSCs. Local food supports the local and regional economy, and well-functioning local markets could be also noteworthy tourist attractions in some areas. They provide basic-level food supply, self-employment and job opportunities.

\section{References}

[1.] Balatoni Integrációs Közhasznú Nonprofit Kft. (2017): Rövid Ellátási Láncok kialakítási lehetőségeinek vizsgálata Somogy és Zala megyében. Helyzetelemzés. Keszthely, 67 p.

[2.] Balázs B. (2011): A helyi élelmiszer-hálózatok fejlesztése. In: Kerekes S. et al. (szerk.): A fenntartható fogyasztás környezeti dimenziói. Aula, Budapest, pp. 277-304.

[3.] Baranyai Zs. - Szabó G. G. (2016): A bizalom tényezői a magyar mezőgazdaságban - Egy felmérés tapasztalatai a Sholtes modell alapján. LVIII. Georgikon Napok, Kivonat kötet. ISBN 978-963-9639-84-3, Keszthely, 47. p.

[4.] Bencsik, A. - Juhász T. (2016): Szervezeti bizalom és bizalmatlanság a sharing economy szellemében. In: LIM2016, Zalaegerszeg, pp. 174-183.

[5.] Benedek, A. - Takácsné, Gy. K. (2016): Bizalmon alapuló együttmüködés vizsgálata kis és középvállalatok körében.In: Vállakozásfejlesztés a XXI. Században. Budapest, 2016, pp. 379-390.

[6.] Benedek Zs. - Balázs B. (2014): A rövid ellátási láncok szocioökonómiai hatásai. Külgazdaság 58 (5-6), pp. 100-120. 
[7.] Beulens, A. J. M. - Broens, D. F. - Folstar, P. - Hofstede, G. J. (2005): Food safety and transparency in food chains and networks. Relationships and challenges. Food Control 16, pp. 481-486.

https://doi.org/10.1016/j.foodcont.2003.10.010

[8.] Byker, C. - Shanks, J. - Misyak, S. - Serrano, E. (2012): Characterizing Farmers' Market Shoppers: A Literature Review. Journal of Hunger \& Environmental Nutrition 7 (1), pp. 38-52.

https://doi.org/10.1080/19320248.2012.650074

[9.] Das, T. K. - Teng, B. S. (2004): The risk-based view of trust: a conceptual framework. Journal of Business and Psychology 19(1), pp. 85-119. https://doi.org/10.1023/B:JOBU.0000040274.23551.1b

[10.] Elghannam, A. - Mesias, F. - Escribano, M. - Fouad, L. - Horrillo, A. Escribano, A. (2020): Consumers' Perspectives on Alternative Short Food Supply Chains Based on Social Media: A Focus Group Study in Spain. Foods 9(2), $13 \mathrm{p}$.

https://doi.org/10.3390/foods 9010022

[11.] Hardin, R. (2002): Trust and Trustworthiness. Russell Sage Foundation, New York, 256 p.

[12.] KSH (2018): Magyarország, 2017. Budapest, 214 p.

[13.] Hendrickson, M. K. - Heffernan, W. D. (2002): Opening spaces through relocalization: locating potential resistance in the weaknesses of the global food system. Sociologia Ruralis 42 (4), pp. 347-369.

https://doi.org/10.1111/1467-9523.00221

[14.] Jarosz, L. (2008): The city in the country: Growing alternative food networks in Metropolitan areas. Journal of Rural Studies 24 (3), pp. 231-244. https://doi.org/10.1016/j.jrurstud.2007.10.002

[15.] Ji, C. - Chen, Q. - Zhuo, N. (2019): Enhancing consumer trust in short food supply chains: The case evidence from three agricultural e-commerce companies in China. Journal of Agribusiness in Developing and Emerging Economies 10(1), pp. 103-116. https://doi.org/10.1108/JADEE-12-2018-0180

[16.] Koncz G. - Szűcs A. (2018): A rövid ellátási láncok vidékfejlesztési jelentősége. In: Dinya L. - Baranyi A. (szerk.) XVI. Nemzetközi Tudományos Napok : „Fenntarthatósági kihívások és válaszok” - A Tudományos Napok Publikációi. EKE Líceum Kiadó, pp. 997-1004. 
[17.] Kujáni K. (2014): Az alternatív élelmiszer-ellátó rendszerek meghatározásának és csoportotsításának tényezői. Gazdálkodás 58 (1), pp. 30-40.

[18.] Kumar, N. (1996): The Power of Trust in Manufacturer-Retailer Relationships. Harvard Business Review 74(6), pp. 93-107.

[19.] Nagy J . - Schubert A. (2007): A bizalom szerepe az üzleti kapcsolatokban. 77. Sz. Mühelytanulmány, BCE Vállalatgazdaságtan Intézet, 25 p.

[20.] Piricz, N. (2013): A bizalmat befolyásoló tényezők vizsgálata az üzleti kapcsolatokban. Vezetéstudomány 44(12), pp. 14-29.

[21.] Sass, J. - Kovács, Z. - Bodnár, É. (2008): „Miben bízhatunk?” - Szervezeti bizalom a szervezeti kultúra tükrében. In: 60 éves a közgáz Jubileumi Tanulmányi Kötet. Budapest, Aula, pp. 49-61.

[22.] Takács, I. - Baranyai, Zs. (2010): Role of trust in cooperation of farmers from the aspect of new institutional economics. ANNALS of the Polish Association of Agricultural and Agribusiness Economists 12 (6). pp. 179-184.

[23.] Tarnai M. (2003): A bizalom szerepe a gazdasági kapcsolatokban. In A Gazdaság és az emberi viszonyok c. fejezet része Gazdaságpszichológia (szerk. Hunyady Gy., Székely M.) Budapest, Osiris, pp. 676-715.

[24.] Varga, J. (2013): A nyitott innovációs üzleti modell és az együttműködésen alapuló piacgazdaság: Vezetés és szervezetek Taylor után 102 évvel. Taylor: Gazdálkodás-és Szervezéstudományi Folyóirat, No. 14-15., pp. 352-363.

[25.] Watts, D. C. - Ilbery, B. - Maye, D. (2005): Making reconnections in agrofood geography: alternative systems of food provision. Progress in human geography 29 (1), pp. 22-40.

https://doi.org/10.1191/0309132505ph526oa

\section{Acknowledgments}

This work was supported by the EFOP-3.6.2-16-2017-00001 research grant. 


\section{Authors}

\section{Antónia Szǘcs (PhD)}

Assistant professor

Eszterházy Károly University

Institute of Rural Development and Landscape Management szucs.antonia@uni-eszterhazy.hu

\section{Gábor Koncz (PhD)}

Associate professor

Eszterházy Károly University

Institute of Rural Development and Landscape Management koncz.gabor@uni-eszterhazy.hu 